\title{
Review of Equity Crowdfunding Practices through Santara.id in the Perspective of Islamic Economic Law
}

\author{
Rahma Octaviani ${ }^{1}$, Pas Ingrid Pamesti ${ }^{2}$, Bagas Heradhyaksa ${ }^{3}$ \\ ${ }^{1}$ International Islamic University Malaysia - Malaysia, ${ }^{2}$ Universitas Negeri Semarang - \\ Indonesia, ${ }^{3}$ Universitas Islam Negeri Walisongo Semarang - Indonesia \\ ${ }^{1}$ octaviani.rahma@live.iium.edu.my, 2pasingrid@gmail.com, \\ 3bagashera@walisongo.ac.id
}

\begin{abstract}
This article aims to find out the mechanism of equity crowdfunding through the santara platform from Islamic economic law. This article uses a qualitative method using library data. This article finds that santara.id is an intermediary between investors and issuers in developing a business. The scheme is similar to the mudärabah contract, the investor is identical to șăhib al-māl, and the issuer is identical to the muḍarib. However, this activity cannot be considered as mudārabah cooperation because there has been no concrete agreement regarding the muḍarrabah agreement. This article provides suggestions so that santaraid can further develop the platform's promotion in the community. It is because santaraid can provide investment services for the middle class, both as investors and issuers.
\end{abstract}

Keywords: equity crowdfunding; investor; issuer; muḍārabah; Islamic economic law

Artikel ini bertujuan untuk mengetahui mekanisme equity crowdfunding melalui platform santara.id dilihat dari perspektif hukum ekonomi Islam. Artikel ini menggunakan metode kualitatif dengan menggunakan data pustaka. Artikel ini menemukan bahwa santara.id merupakan perantara antara investor dan emiten dalam mengembangkan bisnis. Skemanya mirip dengan akad mudārabah, peran investor identik dengan șāhibal-māl dan peran penerbitidentikdengan mudārib. Namun, kegiatan ini tidak dapat dianggap sebagai kerjasama mudārabah karena belum ada kesepakatan yang konkrit mengenai perjanjian mudärabah. Artikel ini memberikan saran agar santara.id dapat lebih mengembangkan promosi platform di masyarakat. Hal ini karena santara.id dapat menjadi solusi dalam memberikan layanan investasi bagi masyarakat menengah, baik sebagai investor maupun emiten.

Kata Kunci: equity crowdfunding; investor; penerbit; muḍārabah; hukum ekonomi Islam 
Rahma Octaviani, Pas Ingrid Pamesti, Bagas Heradhyaksa

\section{Introduction}

The development of financial technology in Indonesia's payment sector in 2017 was $43 \%$ dominating, $17 \%$ lending, while $13 \%$ were aggregators, and the rest were financial planning and crowdfunding based on data from the board of commissioners of the Financial Services Authority. In 2008 the term crowdfunding began to be known; Kickstarter and Indiegogo were the most significant American crowdfunding globally. While in 2012, in Indonesia, such as AyoPeduli.com, Patungan.net, GandengTangan.com, Wujudkan.com, and Kitabisa.com.

Crowdfunding in Indonesia has increased from 6.5 percent to 93.5 percent. Kitabisa.com, AyoPeduli.com, and Joint Venture.net are types of Donation-Based crowdfunding such as education, environment, health, and culture engaged in the non-profit social sector. Some of the crowdfunding platforms that have been mentioned, the only one that still survives and is still actively organizing fundraising, is Kitabisa.com. In 2016 Kitabisa.com conducted the largest transaction in Indonesia, spearheaded by the Indonesian Muslim community in Chiba, Japan, to raise funds for the Chiba Mosque, amounting to IDR 3.2 billion. An example of a platform that operates in the creative industry or Crowdfunding Reward-Based is Wujudkan.com. However, in 2017 after Wujudkan.com was five years old, it did not reach its maximum target, so it was declared to stop operating.

Another type of crowdfunding is debt-based crowdfunding, namely GandengTangan.com which focuses on financing SMEs in Indonesia. Crowdfunding is very useful for business actors who need funds as their business capital. The economy in Indonesia can improve by implementing debt and equity crowdfunding. In 2017 the establishment of GandengTangan.com was accompanied by GT-Trust as a business partner and has distributed IDR 5 billion in funds to 1,200 SMEs in Indonesia. One of the crowdfunding grantees from the DBS Foundation Social Enterprise Grant Program 2018 Singapore is GandengTangan.com. There are 14 active crowdfunding platforms in Indonesia based on AlliedCrowds data, including 10 platforms, the majority of which are 
Debt Based. This proves the progress of MSMEs due to the development of funding platforms in Indonesia. ${ }^{1}$

Crowdfunding has seen tremendous growth and developed into a global billion-dollar business over the past five years. The most successful segment of the nascent market is crowdlending, also referred to as peer-to-peer lending or market lending. New segments such as royalty-based crowdfunding, hybrid forms of crowdfunding, and token presale or Initial Coin Offerings represent relatively small market volumes. Depending on the jurisdiction in which the platforms operate, their business models often bypass traditional financial intermediaries. On the bright side, it can reduce transaction costs and make financial services more cost-effective. In addition, crowdlending portals may be well equipped to develop credit risk models tailored to high-risk loans. As such, they can provide a better assessment of high-risk customers than traditional financial intermediaries who typically deny specific individuals and businesses access to mainstream financial services. In other words, crowdfunding portals have identified the inability of traditional banks to lend as a business opportunity and, as a result, are trying to fill the existing funding gap. At the same time, many crowdfunding markets lack financial intermediaries that screen and monitor borrowers. ${ }^{2}$

In addition, all crowdfunding platforms must be able to be a two-sided marketplace. It means that the platform needs to attract borrowers, start-ups, or charitable beneficiaries, and individuals who are willing to donate or put their money into risky investments. So, if the platforms intend to operate in the market for a sufficiently long period, they must have good incentives to serve the interests of all market participants, including investors. The legal certainty of crowdfunding practice is essential. For example, Chinese crowdlending platform Ezubao has attracted USD 7.6 billion from around 900,000 investors. However, in January 2016, it became clear that the portal was operating a Ponzi

\footnotetext{
${ }^{1}$ AriefYuswanto Nugroho and Fatichatur Rachmaniyah, 'Fenomena Perkembangan Crowfunding di Indonesia', Ekonika: Jurnal Ekonomi Universitas Kadiri 4, no. 1 (April 2019): 34, https://doi.org/ 10.30737/ekonika.v4i1.254.

2 Pas Ingrid Pamesti and Bagas Heradhayksa, 'Kepastian Hukum Mekanisme Equity Crowdfunding Melalui Platform Santara.Id sebagai Sarana Investasi', Jurnal Hukum Ekonomi Islam 4, no. 1 (23 July 2020): 20-37, https://jhei.appheisi.or.id/index.php/jhei/article/view/17.
} 
scheme. The senior executives had spent many investors' money on personal expenses, causing many losses for investors. ${ }^{3}$

This article is intended to describe the mechanism of equity crowdfunding on the santara platform. This research includes qualitative research. It is because this research tries to understand the mechanism of equity crowdfunding in depth. The data collection method used is library research. This article collects data from laws, books, journals, and data on the internet. The nature of this research is descriptive-analytic. It is because this study describes how the public participates in equity crowdfunding activities through the santara.id platform.

\section{Crowdfunding}

The economic crisis that hit Indonesia in 1997/1998 and 2008/2009 showed that small and medium enterprises have proven themselves to be independent business groups with strong resilience. Unfortunately, independent business groups, tiny and micro-businesses with low incomes, cannot get capital or financing from banking institutions because of the lack of financial history. One of the funding solutions for small and micro businesses is microfinance. Several institutions in Indonesia are already engaged in microfinance. However, none have maximized internet technology, mainly social and interactive media sites that can act as catalysts and mobilizers of the masses. $^{4}$

Crowdfunding is a method of raising funds obtained from crowdfunding of the public for all types of businesses, ranging from product ideas and businesses that are already running and receive rewards in the form of goods or services. ${ }^{5}$ The concept of crowdsourcing which provides feedback and solutions for the community to develop their business activities by utilizing the "crowd" of the community, is the root of the crowdfunding concept. Crowdfunding utilizes

\footnotetext{
3 Douglas Cummingand Lars Hornuf, The Economics of Crowdfunding: Startups, Portals and Investor Behavior, The Economics of Crowdfunding: Startups, Portals and Investor Behavior (London: Palgrave Macmillan, Cham, 2018), https://doi.org/10.1007/978-3-319-66119-3.

4 Niko Ibrahim and Verliyantina, "The Model of Crowdfunding to Support Small and Micro Businesses in Indonesia Through a Web-Based Platform', Procedia Economics and Finance 4, no. Crowfunding (2012):390-97,https://doi.org/10.1016/s2212-5671(12)00353-x.

5 Thomas Elliott Young, The Everything Guide to Crowdfunding: Learn How to Use Social Media for Small-Business Funding (USA: Adams Media, 2012).
} 
social media networks such as Facebook, Twitter, LinkedIn, and other sites to raise funds. For entrepreneurs, crowdfunding has the primary goal of providing alternative solutions to obtain funding. ${ }^{6}$

Another literature said the new opportunities to raise funds for businesses and enable non-professional investors to get funding but not use intermediary financial systems through social media networks and online platforms we called "equity crowdfunded".7 The category of fintech implementation is regulated in Bank Indonesia Regulation Number 19/12/PBI/2017 article 3, namely payment systems, market support, investment management, risk management, loans, financing, capital provision, and other financial services. Equity crowdfunding and peer-to-peer or 2P lending are included in one type of fintech service, namely crowdfunding.

Crowdfunding is grouped into four types by the Financial Services Authority, namely, crowdfunding based on capital/shareholding called equitybased crowdfunding, crowdfunding based on credit/debts called lending-based crowdfunding, prize-based crowdfunding called reward-based crowdfunding, and donation-based crowdfunding called donation-based crowdfunding. ${ }^{8}$ The study defines crowdfunding as raising funds from many individuals who are networked and pooling their resources to support efforts initiated by other people or organizations. ${ }^{9}$ The difference is that this effort is carried out through a network of online platforms such as applications or social media.

Crowdfunding is an alternative business funding method that is proliferating and widespread in developing and developed countries to finance a business, loans to individuals or businesses, or other needs through internetbased platforms through fundraising from the public. ${ }^{10}$ According to Valanciene $L$ and Jegeleiciute, crowdfunding is a method that connects entrepreneurs who

\footnotetext{
6 Paul. Belleflame, 'Crowdfunding: An Industrial Organization Perspective', (2010).

7 Mónika Kuti, Zsolt Bedő, and Dorottya Geiszl, 'Equity-Based Crowdfunding', Financial and Economic Review 16, no. 4 (2017): 187-200.

8 Indra, 'The Rout of OJK in Promoting Financing For Innovative and Creative Business Activities', Crowdfunding, Alternative Funding For Creative Business, 2014.

9 D De Buysere, K; Gajda, O; KlevDe Buysere, K; Gajda, O; Kleverlaan, R; Marom, D. (2012). A framework for european crowdfunding. In ... Crowdfunding ... https://d21buns5ku92am.cloudfront. net/26522/documents/17930-1351284179-FRAMEWORK_EU_CROWDFUNDING.pdferlaan, 'A Framework for European Crowdfunding', in EUROPEAN CROWDFUNDING |, 2012, 1-40.

10 C.I. Hutomo, 'Layanan Urun Dana Melalui Penawaran Saham Berbasis Teknologi Informasi (Equity Crowdfunding)', Jurnal Perspektif24, no. 2 (2019): 65-74.
} 
need funding to increase capital and investors who have sources of funds through internet-based intermediary entities. ${ }^{11}$ Crowdfunding is a funding technique for business units or projects that involve the wider community. ${ }^{12}$ The conclusion from several definitions that have been mentioned is that the crowdfunding system correlates entrepreneurs who have creative ideas and business projects that require an injection of funds with investors who have sources of funds. Crowdfunding can be practically integrated by becoming a platform in every sector of economic activity, one of which is in the micro, small, and medium enterprises sector. This crowdfunding system is to realize a particular project or program online by seeking contributions from the wider community. ${ }^{13}$ So, crowdfunding is an internet-based financial intermediation platform to finance a business unit or project by collecting funds from the general public and informing a project proposal.

Crowdfunding has four business models, namely:

1. Donation Based, is an act of donation with social and charitable initiatives used for non-profit projects or programs so that persons with disabilities do not expect profits. However, generally, they will receive rewards in the form of services or goods. ${ }^{14}$

2. Reward-Based, is a program or project that offers rewards in the form of services or rights, goods, for example, in creative industries such as games, where the rewards are in the form of exciting features from the games. ${ }^{15}$

3. Debt Based, the same as credit loans where proposals are submitted from startups or SMEs as debtors and capital deposits in the form of loans in return for interest from crowd investors as creditors. ${ }^{16}$

${ }^{11}$ L. Valanciene and S. Jegeleiciute, 'Crowdfunding for Creating Value: Stakeholder Approach', Precedia-Social and Behavioral Sciences, 2014, 599-604.

12 D.S.F. Akbar, 'Konsep Crowdfunding untuk Pendanaan Infrastruktur di Indonesia', n.d.

13 S. Kocer, 'Sosial Business in Online Financing: Crowdfunding Narrative of Independent Documentary Producer in Turkey', SAGE 17, no. 2 (2014): 231-48.

${ }^{14}$ Hannah Forbes and Dirk Schaefer, 'Guidelines for Successful Crowdfunding', Procedia CIRP 60 (2017): 398-403, https://doi.org/10.1016/j.procir.2017.02.021.

15 A.Y Nugroho and F. Rachmaniyah, 'Fenomena Perkembangan Crowdfunding di Indonesia', Jurnal Ekonika 4, no. 1(2019): 39-41.

16 S.-C. Hsueh and C.-H Kuo, 'Effective Matching for P2P Lending by Mining Strong Association Rules', in 3rd International Conference on Industrial and Business Engineering - ICIBE, ed. Chaoyang University of Technology (Taiwan: ACM Press, 2017), 30-33, https://doi.org/10.1145/3133811.3133823. 
4. Equity-Based, a program from a startup or SME in which the equity (shares) as an owner of the business unit comes from depositing crowd investor funds. Crowd investors get a profit reward from the business unit following the percentage of deposited funds. ${ }^{17}$

There are three main actors in implementing equity crowdfunding; namely, the Equity Crowdfunding platform acts as a financial intermediary that seeks funding for crowd investors via the internet. Publishers are parties who need capital by submitting a funding request proposal through the Equity Crowdfunding platform. Investors see and analyze the investment opportunities offered by the issuer through the equity crowdfunding platform, then commit to funding the program.

\section{Crowdfunding Industry in Other Countries}

Statistics show, in recent years, crowdfunding in the world showed much growth. Concurring to the yearly report of Massolution in 2015 as an industry crowdfunding report, the number of online crowdfunding stages all-inclusive has developed from a simple 100 in 2007 to more than 1,200 in $2014 . .^{18}$ The sum of cash raised universally through crowdfunding was 2.7 billion USD in 2012, 6.1 billion in 2013, and in 2014 there was a 164\% increment in subsidizing volume to reach 16.2 billion USD. The rate of development this industry has been encountering undoubtedly demonstrates that it is worth considering Kickstarter and Indiegogo. Can we see the examples of one platform? However, there are more than 1,000 crowdfunding platforms globally, mainly in North America, Europe, and Oceanic and Asian countries. ${ }^{19}$

Europe has the most supportive and most active countries in using crowdfunding to help grow their small and medium-sized businesses. The UK primarily, with platforms like crowd cubes and funding circles. Then followed by the United States and websites like Lending Club and Prosper that offer personal and entrepreneur loans. Next in the US, there is crowdfunding online

17 Paul Belleflamme, Thomas Lambert, and Armin Schwienbacher, 'Individual Crowdfunding Practices', Venture Capital 15, no. 4 (October 2013): 313-33, https://doi.org/10.1080/13691066. 2013.785151.

18 Laurence Attuel-Mendes, 'Crowdfunding and Crowdmicrofinance, an Evolution of Models for Entrepreneurship of the Poor', Open Access Library Journal Scientific Research 3, no. 12 (2016): 1-7, https://doi.org/10.4236/oalib.1103251.

${ }^{19}$ Fundly, 'Crowdfunding Statistics [Updated for 2020!]', Fundly.com, 2020. 
was by a British shake band named Marillion. Sale delivery the information that they are getting money about $\$ 60,000$ using online gifts by fans of the band visit tour in the US. ${ }^{20}$ The victory of that online raising money was taken after creating a web stage called ArtistShare.com in 2003, committed to helping fans raise reserves for artists and permitting the givers to have got too inventive prepare and preparations as a remunerate. ArtistShare.com, too claims to be the internet's, to begin with, the crowdfunding stage

Kickstarter.com in 2009 came into the crowdfunding field and gave a unique stage for anybody with an imaginative thought to raise reserves. Since its dispatch, Kickstarter has developed to be one of the biggest online stages regarding the number of facilitated projects and stores raised. Features a unique run the show of "all or nothing" subsidizing in Kickstarter suggests that a campaign can reach or surpass its focused subsidizing. However, if it falls brief, all cash is returned to the supporter projected. Based on Kickstarter data, the limited launch countries include the US, UK, Canada, Australia, New Zealand, Netherlands, Denmark, Ireland, Norway, Sweden, Germany, France, Spain, Italy, Austria, Belgium, Switzerland, Luxembourg, Hong Kong, Singapore, Mexico, Japan, Poland, Greece, and Slovenia. ${ }^{21}$

In Malaysia, various types of crowdfunding, such as donations and rewards, have been proven to raise funds for many purposes successfully. There is one crowdfunding project by SocialSharity.com. Pusat Jagaan Siddhartan is the most successful campaign launched to fund an organization that provides school supplies to orphans and disabled children. It was the only successfully funded campaign out of five campaigns listed on SocialSharity.com. This campaign had a goal of MYR 2,160, and the project concluded raised MYR 2,266.80 from 21 donors. ${ }^{22}$ Another literature was shown by the launch of equity crowdfunding (ECF) regulation in Malaysia. Many efforts have been made by the Securities Commission and registered ECF platform to teach people and entrepreneurs in the companies about the alternative financial concepts. ${ }^{23}$ From here, we can see that the growth of crowdfunding shows a significant impact. As stated by

\footnotetext{
${ }^{20}$ Bruce Ronkin, 'Music \& Entertainment Industry Educators Association', Journal of the Music \& Entertainment Industry Educators Association 13, no. 1 (2013): 27.

21 'KICKSTRATER', n.d.

22 Ben Hock Seng, '3 Site for Crowdfunding in Malaysia', EcpatGo.com, n.d.

${ }^{23}$ Liz Bee, 'Malaysian Securities Commision Alows 6 Players to Launch Equity Crowfunding Services', dealstreetasia.com, n.d.
} 
Hoegen et al. that the global crowdfunding mechanism for small businesses and startups will triple, especially in terms of fundraising. Compared to implementing assistance funded from banks or financial institutions, starting from 2012, it has grown by more than 1,000\% to almost over USD 34 billion. ${ }^{24}$ Literature estimated that crowdfunding would make significant improvement by Statista the global crowdfunding market was valued at 12.27 billion U.S. dollars. It was forecast to double by 2027, growing at a compound annual growth rate (CAGR) of 11 percent. ${ }^{25}$

\section{Equity Crowdfunding}

Equity crowdfunding is an information technology-based stock offering through an electronic system carried out by the issuer using the internet network directly to investors to sell shares. It is by the regulation of the Financial Services Authority (OJK) Number 37/POJK.04/2018 concerning Crowdfunding Services through Information Technology-Based Shares Offering (Equity Crowdfunding) Chapter I Article 1. Equity crowdfunding consists of three stakeholders: 1) publishers or business actors who need an injection of funds. 2) companies that provide or organize crowdfunding services. 3) investors or investors as backers.

As a publisher or business actor with a small business scale, submit ideas and requests for funding by issuing shares and offering them to investors or investors on crowdfunding platforms such as start-ups or MSMEs-investors or investors who want to invest in supporting business actors and will get dividends from these investments. Investors and publishers are brought together through a crowdfunding platform as an intermediary. Requirements for stakeholders are by Financial Services Authority Regulation Number 37/PJOK.04/2018. The organizer or intermediary institution or so-called crowdfunding platform, among others, must have a business license from the Financial Services Authority. Limited liability companies and cooperatives can become securities companies with the approval of the Financial Services Authority and registered as electronic system operators at the Ministry of

\footnotetext{
24 Andreas Hoegen, Dennis M. Steininger, and Daniel Veit, 'How Do Investors Decide? An Interdisciplinary Review of Decision-Making in Crowdfunding', Electronic Markets 28, no. 3 (2018): 339-65, https://doi.org/10.1007/s12525-017-0269-y.

25 Statista Research Department, 'Most Successfully Completed Kickstarter Projects as of July 2021, Based on Amount of Total Funds Raised', n.d.
} 
Communication and Information. In addition, he must have a paid-up capital of at least IDR 2.5 billion when applying for a permit, have human resources in the field of information technology, and be able to review the issuing company. Operators must also provide education and training for human resources to improve their quality to improve equity crowdfunding services. The issuer must meet the applicable requirements, including less than 300 shareholders, less than IDR 18 billion total paid-up capital, the publisher is in the form of a Public Company, the assets owned by the publisher excluding land and buildings are more than IDR 10 billion. The last is in the control of the company. The publisher is not controlled directly or indirectly by a business conglomerate, public company, or subsidiary.

There are several risks from crowdfunding investments, namely, firstly, business actors fail, resulting in the value of the investment being wholly lost. When the issuer is liquidated, the issuer cannot provide dividends to investors. Second, in the early years, business actors can fail to pay dividends to investors. Third, the risk if investors cannot sell the shares because the investment is not liquid or the shares are not listed on the stock exchange. Fourth, fraud, fraud, and forgery are very likely to occur through online platforms. Not only that, the probability of cybercrime is very high. Fifth, there are three elements in forming new media, namely platform, channel, and context.26 Platforms are devices such as computers, laptops, cellular phones to access the internet-channels access information, including instant messages, SMS, websites, emails, and social media. At the same time, context is a place to access information, such as at home, at work, on the go, and different time zones and places. When one of the three elements does not function, it poses a risk of service delays, for example, when the internet channel is not accessible from the user's place, resulting in the user not being able to perform equity crowdfunding services, therefore these three elements must always be maintained.

Equity crowdfunding has several advantages, including high risk and high return; buying shares that can grow in large numbers will get big profits toofor example, getting big profits through equity crowdfunding investments by investing in startups during the acquisition of Whatsapp by Facebook and the purchase of Lazada by Alibaba. Then it is easy to invest. Regulations made by the

\footnotetext{
${ }^{26}$ Fikar Damai Setia Gea, 'Crowdfunding: Gerakan Baru Kegotongroyongan di Indonesia (Tinjauan Evolusi Gerakan Aksi Kolektif dalam Media Baru', in Konferensi Nasional Sosiologi V (Padang: Universitas Andalas, 2016), 1131.
} 
Financial Services Authority regarding equity crowdfunding make it easier for stakeholders. Alternative funding for issuers with relatively cheap funds or cost of funds, investors are given open access or not and have been accredited and meet the requirements. As for the organizers of selecting and testing legal permits and their documentation, financial, and administrative processes in the investment process, investors can invest easily, efficiently, and safely.

Equity crowdfunding is a financial service activity in the capital market. However, startups are not required to go through the Initial Public Offering or IPO process or public offering on the Indonesia Stock Exchange or IDX. Based on POJK NO 37 of 2018 article 3, namely Crowdfunding Services or Equity crowdfunding, including stock offerings, not public offerings as referred to in Law of the Republic of Indonesia Number 8 of 1995 concerning Capital Markets. Compared to an IPO, the scale of offering shares through equity crowdfunding is smaller, with a maximum share value of IDR 6 billion, which is offered to investors within a maximum period of 12 months. Based on the Financial Services Authority Regulation No. 37 of 2018 article 30, namely “(1) Based on the agreement with the issuer, the operator can organize and provide a system and/or means to bring together the selling offer and the offer to buy shares of the issuer on the secondary market through the organizer's website. (2) Trading on the secondary market as referred to in paragraph (1) can only be carried out between investors registered with the operator". So the issuer can, at the same time, offer shares through equity crowdfunding, and investors can sell their shares back on the secondary market.

Equity crowdfunding is emerging as an increasingly important source of entrepreneurial funding. Supportive, informal institutions are critical to the development of the Equity crowdfunding industry and market. Building a climate of trust and high-quality relationships between entrepreneurs and investors are essential prerequisites for developing the Equity Crowd Funding market. The creation of trust in online transactions is also essential. One crucial observation relevant to countries characterized by less supportive informal institutions is that these institutions are changing. Among the mechanisms through which more supportive, informal institutions can be developed, enacting and enforcing Equity Crowd Funding regulations and developing highquality relationships among key actors. More supportive institutions are also likely to develop as the Equity Crowd Funding market becomes more mature and attracts many participants. 
Rahma Octaviani, Pas Ingrid Pamesti, Bagas Heradhyaksa

\section{Investment}

Future benefits and profits are always associated with investing activities. Simply put, humans think of investment as something that we buy and generate more profit than expenses incurred. Current expenditures that are not consumed and the period as a benchmark is called investment. There are three types of investment, namely short-term investment, medium-term investment, and long-term investment. The commitment of several funds to the expected future profits as a unit of compensation and future uncertainty gave the prevailing inflation rate is also known as investment.

Many institutions are currently issuing investment programs for the public through bonds, stocks, mutual funds, and even cryptocurrencies, generally known as bitcoin. The government needs special attention based on the Law and Law on Protection of investment actors to prevent losses and failures in the expectation of future income results. SEC (Securities and Exchange Commission (SEC) and FINRA (Financial Industry Regulatory Authority) are examples of institutions that enforce applicable laws, regulations, and industry standards in support of permitted investment performance. OJK is one of the institutions in Indonesia that supports and protects all financial and banking activities in Indonesia, including investment. It is hoped that investment actors will understand the risks and benefits of the investment they are going to buy by conducting product-related analysis before agreeing to an agreement.

\section{Description about Santara}

PT Santara Daya Inspiratama, better known as the Santara brand, as a provider of crowdfunding technology financial services, strives always to be honest in providing financial information and the ability of publishers to share profits with investors. At the start-up level, this company had experienced a freeze or was frozen because of the OJK permit and was considered a fraudulent investment. After that, the regulator provided guidelines that in maintaining the company's quality, it must have system security, Indonesia as the server location, all data is maintained, and the system meets the CIA (Confidentiality, Integrity, and Availability).

Santara acts as a liaison between investors or parties with surplus funds and those who need funds or are commonly referred to as stock issuers. Stock issuers are usually micro, small, and medium enterprises. In addition, Santara 
reviewed whether or not the publisher's business was offered to investors. The point of sale (POS) platform or cashier and cashless applications via online or payment applications is used to find out information about the publisher's business conditions that are incorrect or fraudulent. To convince investors to invest their funds in Fintech equity crowdfunding, how is the security and protection of their investment assets, Santara will assess the issuer's business performance. To carry out this task, Santara collaborates with financial consultants. In addition, Santara also provides facilities so that investors and publishers can have online meetings. Santara also cooperates with PT Kustodian Sentral Efek Indonesia to manage the portfolio of investors. Currently, 63 business actors as publishers in Santara have received capital injections reaching IDR 84.5 billion. There are 13,200 of the 220,000 registered investors who are active in Santara doing the funding. ${ }^{27}$

Bookkeeping, financial management, tax payments, and corporate assets are the four components presented by Santara. Santara positions himself as a companion and teaches the four components. Santara provides and organizes an equity crowdfunding system or investment fundraising that plays a role in bringing together investors and publishers, overseeing business processes to run by applicable regulations, and conducting business reviews on prospective issuers who need funding. 28

PT Santara Daya Inspiratama is a company that obtained the first license to provide crowdfunding services through an equity crowdfunding-based share offering and supervised by the Financial Services Authority based on Decree Number: KEP-59/D.04/2019 issued in early September 2019. Supervision by the Authority Financial services for Equity Crowdfunding activities can be carried out by two methods: off-site or on-site. The Financial Services Authority is also required to mitigate risk, either through regulation or through concrete steps. The Financial Services Authority can cooperate with the Indonesian Fintech Association in the context of risk mitigation. It is to increase the confidence of investors or publishers in their activities on the Equity Crowdfunding platform. ${ }^{29}$ Therefore, Santara is expected to provide growth

\footnotetext{
27 https://finansial.bisnis.com/read/20200821/563/1281507/fintech-santara-milik-mardiguwowiek-diklaim-lebih-transparan

${ }^{28} \mathrm{https} / / /$ santara.co.id/pertanyaan

${ }^{29}$ Irawati, 'Supervisory Role of The Financial Services Authority in Utilizing Equity Crowdfunding in Indonesia', Law Reform 16, no. 1 (2020):32-44, https://doi.org/10.14710//r.v16i1.30303.
} 
space for SMEs or start-ups to access funding through the capital market. In addition, it is hoped that it can contribute to increasing financial inclusion.

In 2012, PT Santara Daya Inspiritama was formed in Yogyakarta. Santara is a crowdfunding financial technology service provider for various small businesses or SMEs. A total of 1,082 people are registered investors in activities at Santara. Any issuer in the crowdfunding operator that conducts a share offering is not considered a public offering by Law Number 8 of 1995 concerning the Capital Market, even though the service already has a permit from the Financial Services Authority. The share offering period is a maximum of 12 months, and the total funds raised through the share offering are a maximum of IDR 10 billion. ${ }^{30}$

\section{Mechanism of Santara}

Santara is a service that provides facilities for the public to get the opportunity to become Investors and Publishers. As investors, investors can buy SME business shares in Santara. Investors also can get dividends from these SMEs as the Publisher can offer shares of its SME business to Investors through the Santara intermediary. The issuer can use the proceeds from the sale of shares to develop its SME business. Santara's role is to bring together publishers and investors by reviewing prospective publishers' businesses that need funding. Santara also provides an equity crowdfunding system or investment fundraising system. Besides that, Santara acts as a liaison between investors, issuers, and relevant regulators. In addition, Santara also actively continues to supervise all activities of investors and publishers so that they do not conflict with existing legal regulations.

Most people think investing in SME businesses is by directing the SME business owner to negotiate and get an attractive agreement to invest in the SME. However, Santara offers convenience in investing, including Santara has many business options. Investors who invest in SMEs in Santara have the opportunity to get dividends without the need to be involved in the business operations of the invested SMEs. The services provided by Santara, starting from selecting SMEs to get dividends, can be carried out on one platform. Besides that, at Santara, owning a part of the stake in the SME business starts

30 https://bisnis.tempo.co/read/1251904/ojk-keluarkan-izin-untuk-layanan-urun-danasantara/full\&view $=0 \mathrm{k}$ 
with relatively affordable capital. Santara has a Pre-listing feature to review and assess businesses that are Publishers at Santara. The assessment is carried out fairly and thoroughly. Prospective investors can join Santara by registering on the application, then waiting for the data that has been filled in to be verified by the admin for a maximum of 2 working days. If it has been verified, investors can invest in Santara.

After registering, investors can make a deposit to top up the balance and can directly purchase the shares that are being offered. The balance can also be taken back with an administration fee of IDR 25,000 for each withdrawal transaction with an estimated time of 2 working days. Santara provides three choices of payment methods, namely deposit balances, virtual accounts, and manual transfers. First, the payment method using a deposit balance is intended for investors who do not want to run out of business shares that are currently offering shares. The advantage of this method is the automatic verification process so that investors can be verified successfully. Second, through the virtual account method, PT Sinar Digital Ter Depan (Xendir) was chosen by Santara as the payment gateway. The payment process is automatic so that the payment will be verified. The three payment methods using manual transfers can be made either by depositing cash, ATM, M-Banking, or internet banking to an account number in the name of PT Santara Daya Inspiratama by including proof of payment to the system to be verified by the team manually within a maximum of 1 working day.

The purchase of shares is said to be successful not when making a booking but when the system has verified the investor's payment and received an email proof of the purchase. Like in capital market activities, the investor's portfolio will be officially registered at PT Kustodian Sentral Efek Indonesia. After that, investors or investors will get information about the dividend distribution period and the development of the business whose shares have been purchased.

Investors need to analyze the information presented in the issuer's line of business in the prospectus to minimize the risk of loss. The analysis starts from the issuer's method to increase business scale and increase profit income and various other factors that are not exposed in the prospectus and conduct their risk assessment of the ability of the risk that can be borne. This analysis is a consideration for investors in the future.

Santara also works to minimize losses as the organizer of equity crowdfunding, including conducting a review of prospective issuers, including 
the legal aspect. The legal aspects consist of aspects of legal entities to aspects of business licensing that will be given funding. The next effort is to educate investors so that they can make the right decisions. Finally, evaluate the course of cooperation between investors and publishers.

Investors can sell shares after passing one year from issuance. The process of selling shares can be done through the secondary market on the Santara platform. Referring to OJK regulations and decisions regarding the Secondary Market, the service is opened twice in 1 year. The following process is the deposit of securities at PT Kustodian Sentral Efek Indonesia (KSEI). Currently, the administrative process of Santara and KSEI has been completed. The next step is the coordination of technical adjustments.

Dividends obtained by investors are decided through the GMS mechanism. Each issuer has a different dividend distribution schedule, some every six months and every 12 months. The dividend period is stated in the prospectus when the initial business is offered to the public. Dividend Yield Projection is also included in the prospectus to estimate dividends that investors can obtain. The amount of dividends given to investors is distributed proportionally according to share ownership. The value of dividends distributed to investors has been deducted by tax dividends so that reaching investors is the final dividend value.

Santara is an organizer that brings together issuers and investors. At the same time, those who are fully responsible for the course of business activities are the issuer's management. Santara only acts as the investor's representative as the issuer's shareholder, including during the general meeting of the issuer's shareholders and the signing of the deed and other related documents. Santara as the organizer also monitors the Publisher's business in the context of risk management. However, if the Publisher's business is closed, the process will refer to the existing legal regulations so that the liquidation of fixed assets can protect investors.

Investors can provide input to publishers so that the business is maintained. If an investor feels like selling his shares, he can sell them through the secondary market. It is the investor's personal decision whether he wants to continue investing his money or sell it. Santara also provides pre-listing services in its share buying and selling activities. It means that Santara has provided information regarding businesses that will soon be funded. Thus, providing an opportunity for investors to learn the business. 
Publishers must meet three principles in Santara, namely profitable, accountable, and sustainable. The profitable principle is that a business whose data is registered is a business that is already running, has customers, and is profitable. The principle of accountability means that the issuer can run the business with clear and transparent governance. The organization's division, legality, the owner's credibility, financial reports, and track record of the business are all clear and open. The principle of sustainability is choosing a business that can grow or survive in the long term, not a temporary trend, or has the potential to decline in the next few years. Prospective publishers on Santara can garner support from Santara users on the Santara Pre-listing, a stock offering board where new businesses register. Santara users, especially potential investors, can learn about, leave reviews, and support the businesses they love, so they can quickly qualify for the main stock offering boards.

\section{Analysis of Equity Crowdfunding Practices in the Santara.id Platform from the Perspective of Islamic Economic Law}

Linguistically, mudārabah means hitting, or it can also be understood as a word to move. In terms of mudārabah is an activity to move a business. ${ }^{31}$ Therefore, the term mudārabah is often used as an agreement system in business cooperation. There are two parties in the mudārabah contract, namely the party who has the funds, in Arabic referred to as șăhib al-māl, and the party who runs the business or commonly referred to as mudārib. ${ }^{32}$

Muslim scholars explained at least five conditions to run a mudārabah agreement, namely capital, business, profit, consent, and the parties. ${ }^{33}$ In order to implement a mudârabah agreement, it must be determined from the beginning regarding the distribution of capital from a business. The business that is run must also be transparent and open. Each party must know every detail of the business. Furthermore, profit-sharing must also be explained and agreed upon by both parties. Each party must agree to the agreement. Thus, each party understands the role of investors and businesspeople. Finally, each

31 Abu Azam Al Hadi, Fikih Muamalah Kontemporer (Jakarta: RajaGrafindo Persada, 2017), 2.

32 Maskur Rosyid and Fitria Nurdina, 'Mudharabah dan Murabahah; Pengaruhnya terhadap Laba Bersih BUS', Islaminomic 6, no. 2 (August 2015): 62-63, http://jurnal.stesislamicvillage.ac.id/ index.php/JURNAL/article/viewFile/39/34; Dimyauddin Zuhri Qudsy, Pengantar Fiqih Muamalah (Yogyakarta: Pustaka Pelajar, 2008), 224.

33 Syafe'i Rachmad, Fiqih Muamalah (Bandung: Pustaka Setia, 2001), 225. 
party who follows the agreement must be a legally capable person. ${ }^{34}$ The provisions regarding the mudārabah have also been written in the fatwa of the Indonesian Council of Ulama No: 115/DSN-MUI/LX/2017 regarding the Muḍārabah Contract.

There are five conditions in the mudārabah contract, namely capital, business, profit, contract, and the parties. Almost all mudārabah requirements are contained in the equity crowdfunding practice at Santara.id. There are two essential parties in equity crowdfunding: investors as owners of funds and issuers as business actors. To be able to conduct an equity crowdfunding campaign, the business to be run must be right. Business capital is obtained from investors. From the beginning, it was agreed to share the profits between the issuer and the investor. Alonso (2015) conducted a case study of the Egyptian SEC platform called Shekra, which developed a business model based on positive values and social responsibility. 35

Interestingly, fundraising through Shekra is done in an Islamic way. Entrepreneurs should not use the collected funds for business activities that are not by Islamic teachings. By law, investors who hold specific equity in the project will be rewarded based on the distribution of profits and losses. Shekra also acts as a partner and shares equity as funds begin to flow to ensure long-term commitment.

The implementation of equity crowdfunding in the sharia concept must follow four rules: trustworthy, no interest, wealth should be based on the principle of distribution, and social responsibility. MUI Fatwa No: 115/DSNMUI/LX/2017 concerning Muḍarabah states that the muḍarabah contract is a business cooperation agreement between capital owners that provides all capital to the manager and the business profits are divided between them according to the ratio agreed in the contract.

The cooperation agreement in the Santara.id equity crowdfunding platform is substantially identical to the mudärabah cooperation agreement. The concept is, Santara.id, as the organizer of equity crowdfunding, brings together investors as owners of funds and issuers as owners and business actors. If the business

\footnotetext{
34 Hadi, Fikih Muamalah Kontemporer, 3-4.

35 Inmaculada Macias Alonso, 'Crowdfunding in Islamic Finance and Microfinance -ACase Study of Egypt', Islamicmarket.com, 2016.
} 
makes a profit, investors will get a profit share. On the other hand, if the business suffers a loss, the investor will also bear the loss. So, substantially the concept of equity crowdfunding is identical to the concept of muda arabah. However, in the practice of equity crowdfunding, there is no agreement stating that the cooperation is a mudārabah contract. Thus, it cannot be called a mudārabah contract.

\section{Conclusion}

Equity crowdfunding is a mechanism that brings together investors and issuers in developing businesses using internet intermediaries. Santara.id is a platform that provides equity crowdfunding services. There is no minimum amount limit to become an investor at santara.id. For the minimum purchase of shares, refer to the Regulation of the Financial Services Authority Number 37/POJK.04/2018; the minimum amount of share purchase is the number of funds offered divided by the maximum remaining shareholders on behalf of the community. So, the minimum purchase of shares for each issuer can be different. Becoming an issuer at santara.id is also not as difficult as being an issuer in the capital market. It is an opportunity for micro, small or medium enterprises to be able to get financing. Thus, Santara becomes a provider of investment facilities for the middle class, both as investors and issuers. From the perspective of Islamic economic law, the practice of equity crowdfunding at Santara.id is identical to the substance of the mudarrabah contract. Investors have similar roles such as șăhib al-māl and issuers have similar roles with mudârib. Not only are profits shared, but also losses. However, the equity crowdfunding partnership at santara.id cannot be considered a mudārabah contract because no agreement states that the partnership is muārabah.

\section{Suggestion}

Santara.id is the only digital platform that has official permission from the Financial Services Authority. Thus, it becomes a safe investment platform amid rampant fictitious investments that harm the community. The legal certainty that santara.id has can be used to gain public trust. Meanwhile, for further research, the theme of equity crowdfunding still leaves room in reviewing Islamic economic law. It is because equity crowdfunding is very synonymous with the mudianabah concept. To state that equity crowdfunding is a lawful or unlawful contract, a more in-depth study is necessary.[a] 
Rahma Octaviani, Pas Ingrid Pamesti, Bagas Heradhyaksa

\section{BIBLIOGRAPHY}

Akbar, D.S.F. 'Konsep Crowdfunding untuk Pendanaan Infrastruktur di Indonesia', n.d.

Belleflame, Paul. 'Crowdfunding: An Industrial Organization Perspective'. 2010.

Belleflamme, Paul, Thomas Lambert, and Armin Schwienbacher. 'Individual Crowdfunding Practices'. Venture Capital 15, no. 4 (October 2013): 31333. https://doi.org/10.1080/13691066.2013.785151.

Buysere, K; Gajda, O; KlevDe Buysere, K; Gajda, O; Kleverlaan, R; Marom, D. (2012). A framework for european crowdfunding. In ... Crowdfunding .... https://d21buns5ku92am.cloudfront.net/26522/documents/179301351284179-FRAMEWORK_EU_CROWDFUNDING.pdferlaan, D De. 'A Framework for European Crowdfunding'. In EUROPEAN CROWDFUNDING /, 1-40, 2012.

Cumming, Douglas, and Lars Hornuf. The Economics of Crowdfunding: Startups, Portals and Investor Behavior. London: Palgrave Macmillan, Cham, 2018. https://doi.org/10.1007/978-3-319-66119-3.

Department, Statista Research. 'Most Successfully Completed Kickstarter Projects as of July 2021, Based on Amount of Total Funds Raised', n.d.

Forbes, Hannah, and Dirk Schaefer. 'Guidelines for Successful Crowdfunding'. Procedia CIRP 60 (2017): 398-403. https://doi.org/10.1016/j.procir. 2017.02.021.

Fundly. 'Crowdfunding Statistics [Updated for 2020!]'. Fundly.com, 2020.

Gea, Fikar Damai Setia. 'Crowdfunding: Gerakan Baru Kegotongroyongan di Indonesia (Tinjauan Evolusi Gerakan Aksi Kolektif dalam Media Baru'. In Konferensi Nasional Sosiologi V,1131. Padang: Universitas Andalas, 2016.

Hadi, Abu Azam Al. Fikih Muamalah Kontemporer. Jakarta: RajaGrafindo Persada, 2017.

Hoegen, Andreas, Dennis M. Steininger, and Daniel Veit. 'How Do Investors Decide? An Interdisciplinary Review of Decision-Making in Crowdfunding'. Electronic Markets 28, no. 3 (2018): 339-65. https:// doi.org/10.1007/s12525-017-0269-y.

Hsueh, S.-C., and C.-H Kuo. 'Effective Matching for P2P Lending by Mining Strong Association Rules'. In 3rd International Conference on Industrial and Business Engineering - ICIBE, edited by Chaoyang University of Technology, 30-33. Taiwan: ACM Press, 2017. https://doi.org/ $10.1145 / 3133811.3133823$. 
Hutomo, C.I. 'Layanan Urun Dana Melalui Penawaran Saham Berbasis Teknologi Informasi (Equity Crowdfunding)'.Jurnal Perspektif 24, no. 2 (2019): 6574.

Ibrahim, Niko, and Verliyantina. 'The Model of Crowdfunding to Support Small and Micro Businesses in Indonesia Through a Web-Based Platform'. Procedia Economics and Finance 4, no. Crowfunding (2012): 390-97. https://doi.org/10.1016/s2212-5671(12)00353-x.

Indra. 'The Rout of OJK in Promoting Financing For Innovative and Creative Business Activities'. Crowdfunding, Alternative Funding For Creative Business, 2014.

Inmaculada Macias Alonso. 'Crowdfunding in Islamic Finance and Microfinance -ACase Study of Egypt'. Islamicmarket.com, 2016.

Irawati. 'Supervisory Role of The Financial Services Authority in Utilizing Equity Crowdfunding in Indonesia'. Law Reform 16, no. 1 (2020): 32-44. https://doi.org/10.14710/lr.v16i1.30303.

'KICKSTRATER', n.d.

Kocer, S. 'Sosial Business in Online Financing: Crowdfunding Narrative of Independent Documentary Producer in Turkey'. SAGE 17, no. 2 (2014): 231-48.

Kuti, Mónika, Zsolt Bedő, and Dorottya Geiszl. 'Equity-Based Crowdfunding'. Financial and Economic Review 16, no. 4 (2017): 187-200.

Laurence Attuel-Mendes. 'Crowdfunding and Crowdmicrofinance, an Evolution of Models for Entrepreneurship of the Poor'. Open Access Library Journal Scientific Research 3, no. 12 (2016): 1-7. https://doi.org/10.4236/oalib. 1103251.

Liz Bee. 'Malaysian Securities Commision Alows 6 Players to Launch Equity Crowfunding Services'. dealstreetasia.com, n.d.

Nugroho, A.Y, and F. Rachmaniyah. 'Fenomena Perkembangan Crowdfunding di Indonesia'. Jurnal Ekonika 4, no. 1 (2019): 39-41.

Nugroho, Arief Yuswanto, and Fatichatur Rachmaniyah. 'Fenomena Perkembangan Crowfunding di Indonesia'. Ekonika: Jurnal Ekonomi Universitas Kadiri 4, no. 1 (April 2019): 34. https://doi.org/10.30737/ ekonika.v4i1.254.

Pamesti, Pas Ingrid, and Bagas Heradhayksa. 'Kepastian Hukum Mekanisme Equity Crowdfunding Melalui Platform Santara.Id sebagai Sarana Investasi'. Jurnal Hukum Ekonomi Islam 4, no. 1 (23 July 2020): 20-37. https://jhei.appheisi.or.id/index.php/jhei/article/view/17. 
Rahma Octaviani, Pas Ingrid Pamesti, Bagas Heradhyaksa

Qudsy, Dimyauddin Zuhri. Pengantar Fiqih Muamalah. Yogyakarta: Pustaka Pelajar, 2008.

Rachmad, Syafe'i. Fiqih Muamalah. Bandung: Pustaka Setia, 2001.

Ronkin, Bruce. 'Music \& Entertainment Industry Educators Association'. Journal of the Music \& Entertainment Industry Educators Association 13, no. 1 (2013): 27.

Rosyid, Maskur, and Fitria Nurdina. 'Mudharabah dan Murabahah; Pengaruhnya terhadap Laba Bersih BUS'. Islaminomic 6, no. 2 (August 2015). http://jurnal.stesislamicvillage.ac.id/index.php/JURNAL/article /viewFile/39/34.

Seng, Ben Hock. '3 Site for Crowdfunding in Malaysia'. EcpatGo.com, n.d.

Thomas Elliott Young. The Everything Guide to Crowdfunding: Learn How to Use Social Media for Small-Business Funding. USA: Adams Media, 2012.

Valanciene, L., and S. Jegeleiciute. 'Crowdfunding for Creating Value: Stakeholder Approach'. Precedia-Social and Behavioral Sciences, 2014, 599-604.

World Bank. 'Crowdfunding's Potential for the Developing World'. In Finance and Private Sector Development Department, 1-102, 2013. 